\title{
Proteins released during high toxin production in Clostridium difficile
}

\author{
Kakoli Mukherjee, ${ }^{3}$ Sture Karlsson, ${ }^{1,2}$ Lars G. Burman $^{1}$ \\ and Thomas Åkerlund ${ }^{1}$
}
1 Department of Bacteriology, Swedish Institute for Infectious Disease Control, S-17182, Solna, Sweden
2 Microbiology and Tumor Biology Center, Karolinska Institute, S-17177 Stockholm, Sweden
3 AstraZeneca Research Center India, PO Box 359 Malleswaram, 560003 Bangalore, India

\author{
Author for correspondence: Thomas Ảkerlund. Tel: +468 4572467. Fax: +468301797. \\ e-mail: Thomas.Akerlund@smi.ki.se
}

\begin{abstract}
The mechanism by which toxins A and B are released by Clostridium difficile is unknown and information about the other extracellular proteins of this bacterium is limited. The authors identified exported proteins from $C$. difficile strain VPI 10463 during conditions promoting high toxin production. Toxins A and $B$ were released in a 1:1 ratio and the proportion of toxin in the extracellular fraction reached $50 \%$ during the stationary phase as compared to a proportion of $<1 \%$ for typical cytoplasmic proteins, showing that toxin export was not due to bacterial lysis. A $47 \mathrm{kDa}$ protein, released with similar kinetics to the toxins, was processed and showed weak similarity to the channel-forming protein TolC. Another protein released during high toxin production was unprocessed and showed similarity to XkdK encoded by the prophage PBSX in Bacillus subtilis, a protein supposedly exported via phagespecific holins. The two most abundant extracellular $C$. difficile proteins, found during both high and low toxin production, were processed and identified as shed S-layer proteins. As shown by $\mathbf{N}$-terminal sequencing and PCR-based methods, there was a considerable sequence variation of the S-layer gene sIpA in different serogroup reference strains. To conclude, $\boldsymbol{C}$. difficile uses the classical Sec-dependent and probably also holin-like pathways to secrete a comparatively small repertoire of proteins.
\end{abstract}

Keywords: extracellular proteins, outer membrane efflux proteins, PBSX prophage, Slayer

\section{INTRODUCTION}

Clostridium difficile-associated diarrhoea (CDAD), occasionally complicated by pseudomembranous colitis (PMC), has become a major hospital problem usually caused by antibiotics that perturb the large-bowel microflora, facilitating colonization and overgrowth by C. difficile (Lyerly \& Wilkins, 1995). The virulence factors of $C$. difficile comprise two closely related toxins, $\mathrm{A}$ and $\mathrm{B}$, with predicted molecular masses of 308 and $270 \mathrm{kDa}$, respectively (Dove et al., 1990; von EichelStreiber et al., 1992). The toxins are endocytosed by the intestinal epithelial cells and glycosylate small GTPbinding proteins, e.g. Rho, Rac and Cdc42, resulting in disruption of the actin cytoskeleton and finally, cell death (von Eichel-Streiber et al., 1996).

The $t c d A(t o x A)$ and the $t c d B(t o x B)$ genes are part of a $19.6 \mathrm{~kb}$ pathogenicity locus (PaLoc, toxigenic element), which comprises five ORFs (Braun et al., 1996; von Eichel-Streiber et al., 1992; Hammond \& Johnson,
1995). Several mRNAs are transcribed from the toxigenic element, including a $17.5 \mathrm{~kb}$ polycistronic transcript (Hammond et al., 1997; Hundsberger et al., 1997). One of the genes, $t c d D(t x e R)$, encodes a $22 \mathrm{kDa}$ protein necessary for transcription of the toxin genes (Moncrief et al., 1997) and was recently shown to act as an alternative sigma factor (Mani \& Dupuy, 2001).

The toxin yield or activity may differ up to $10^{6}$-fold between toxin-positive strains (Lyerly \& Wilkins, 1986). The toxins are expressed mainly during the late exponential growth phase and the stationary phase (Kamiya et al., 1992; Ketley et al., 1986), and limiting nutrient levels (e.g. glucose, amino acids, biotin) lead to upregulation of toxin expression (Dupuy \& Sonenshein, 1998; Haslam et al., 1986; Karlsson et al., 1999, 2000; Yamakawa et al., 1994, 1996. Toxin export occurs by an unknown mechanism during the stationary phase (Ketley et al., 1984), and may be affected by the oxidation-reduction potential of the medium, heat shock, and certain antibiotics (Onderdonk et al., 1979). 


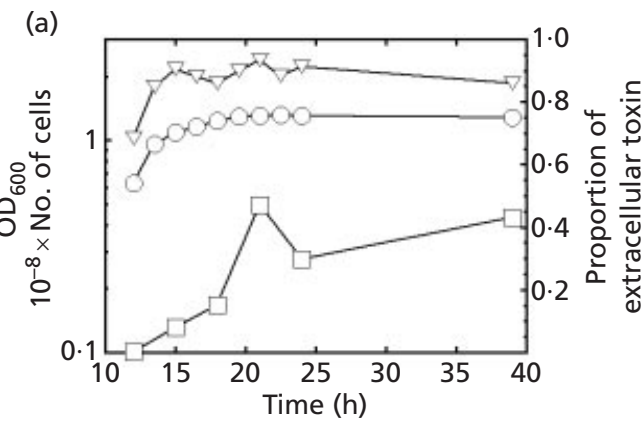

(b)

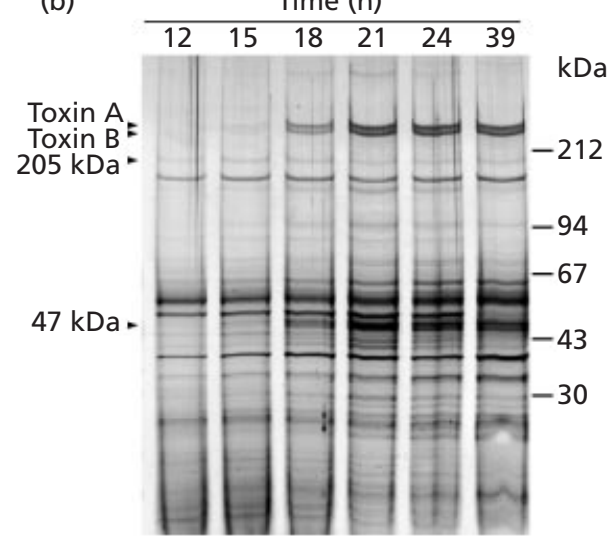

(c)

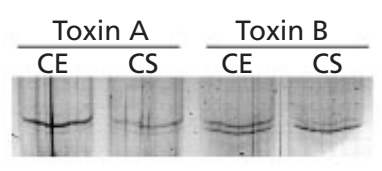

(d)

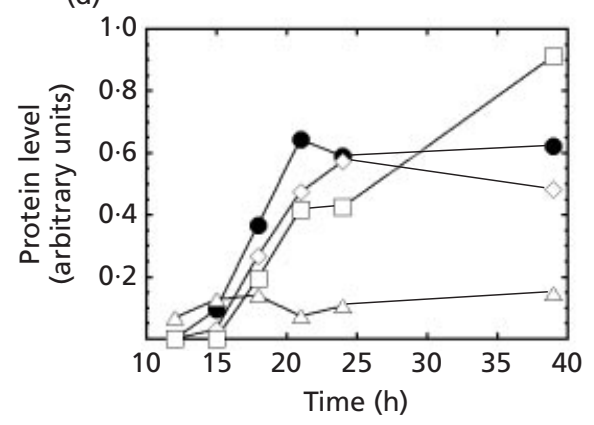

Fig. 1. Release kinetics of toxins and other proteins by $C$. difficile strain VPI 10463. (a) Growth curve $\left(O, O D_{600} ; \triangle\right.$, total count) and proportion of extracellular toxins $A$ and $B$ measured by enzyme immunoassay ( $\square$ ). (b) Extracellular proteins analysed by SDS-PAGE and silver staining. A volume corresponding to $0.5 \mu \mathrm{g}$ intracellular protein was applied in each lane. Arrows point to proteins of interest. (c) Identification of toxins $A$ and $B$ in cell extract (CE) and supernatant (CS) fractions from PY cultures by immunoprecipitation. Approximately $100 \mu \mathrm{l}$ culture extract was precipitated and $50 \%$ of the precipitated proteins were applied in each lane. (d) Relative intensity of toxins $A$ $(\bullet)$ and $B(\diamond)$ and two other proteins $(\square, 47 \mathrm{kDa} ; \triangle, 205 \mathrm{kDa})$ measured using Totallab software (Amersham Biosciences).

The toxin export mechanism remains obscure, but due to their large size and lack of secretion signal peptides, one hypothesis is that the toxins are externalized by bacterial lysis. The aim of this study was to investigate the toxin export kinetics and to identify other extracellular proteins and putative virulence factors in the culture supernatant of $C$. difficile. Bacterial lysis could not explain release of toxins in the high-toxin-producing strain C. difficile VPI 10463. Five other extracellular proteins were identified and characterized at the protein and the genomic levels.

\section{METHODS}

Strains, growth media and toxin measurements. The $C$. difficile strains were CCUG 19126 (VPI 10463), CCUG 37766-37787 (serotype reference strains) from the Culture Collection, University of Göteborg, Sweden, and strain 630. Bacteria were grown in peptone-yeast with (PYG) or without (PY) glucose. Medium was prepared as described previously (Karlsson et al., 1999). Toxin yield was measured using the Ridascreen C. difficile Toxin A/B enzyme immunoassay kit (r-Biopharm).

Sample preparation and membrane fractionation. Culture samples were centrifuged at $16000 \mathrm{~g}$ for $3 \mathrm{~min}$; the resulting supernatants were removed and stored at $-20{ }^{\circ} \mathrm{C}$ for later analysis. The cell pellet was dissolved in $1 \mathrm{ml}$ sterile water and sonicated on ice for $3 \times 30 \mathrm{~s}$ at $100 \mathrm{~W}$ (Labsonic 1510, B. Braun). The cell extracts were centrifuged at $5000 \mathrm{~g}$ for $5 \mathrm{~min}$, giving a low-speed pellet (LSP). The supernatant was removed and further centrifuged at $50000 \mathrm{~g}$ for $20 \mathrm{~min}$, resulting in a high-speed pellet (HSP) and a soluble fraction. The LSP and the HSP were resuspended in PBS and all samples were stored at $-20^{\circ} \mathrm{C}$. Protein was measured using a kit (Bio-Rad) and a BSA standard curve according to the manufacturer's instructions. Proteins in culture supernatants were precipitated in $10 \%$ trichloroacetic acid.

SDS-PAGE and immunoprecipitation. Proteins were analysed by SDS-PAGE (ExcelGel 8-18\%, Amersham Biosciences) on a Multiphor II horizontal slab gel apparatus and stained with silver. The gels were digitized by scanning (Scanjet 3c/T, Hewlett Packard) and analysed using the Totallab software (Amersham Biosciences). Immunoprecipitation was performed in microtitre wells coated with antibodies against toxin A (PCG-4, r-Biopharm) or toxin B (2CV, r-Biopharm). Antibody $\left(10 \mu \mathrm{g} \mathrm{ml}^{-1}\right.$ in $40 \mathrm{mM} \mathrm{Na} \mathrm{CO}_{3}, 60 \mathrm{mM} \mathrm{NaHCO}$, $\mathrm{pH}$ 9.6) was coated in microtitre wells by incubation for $1 \mathrm{~h}$ at $37^{\circ} \mathrm{C}$. The wells were washed four times with PBS containing $0.05 \%$ (v/v) Tween 20, pH 7.4. The wells were loaded with cell extract, culture supernatant medium or PBS (negative control), incubated for $1.5 \mathrm{~h}$ at $25^{\circ} \mathrm{C}$, and washed four times with PBS. Fifty microlitres of SDS sample buffer was added to each well and the samples were heated to $95^{\circ} \mathrm{C}$ for 5 min prior to analysis by SDS-PAGE.

Two-dimensional (2-D) PAGE. For 2-D PAGE, $40 \mu \mathrm{l}$ aliquots of each protein sample (see above) were mixed with $160 \mu \mathrm{l}$ buffer [9.9 M urea, 4\% (v/v) Igepal CA630, 2.2\% (v/v) Pharmalytes 3-10, $100 \mathrm{mM}$ DTT, 2\% (w/v) CHAPS]. Proteins were focused at $20^{\circ} \mathrm{C}$ on $180 \mathrm{~mm}$ IPG Drystrip pH 4-7 (Amersham Biosciences). The second dimension was run on $12 \%$ SDSPAGE and proteins were stained with silver. PDQuest (Bio$\mathrm{Rad})$ were used to quantify proteins. The chemicals were obtained from Sigma except for Pharmalytes (Amersham Biosciences). Proteins were transferred to PVDF membranes, 
(a)

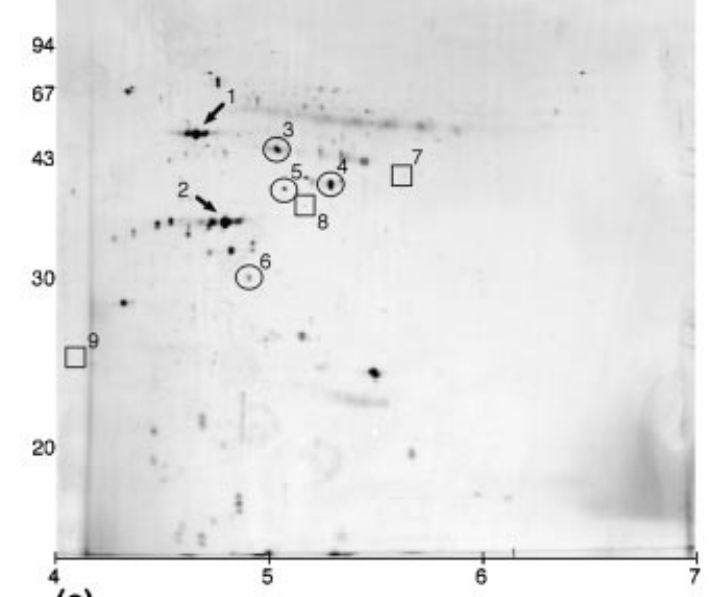

(c)

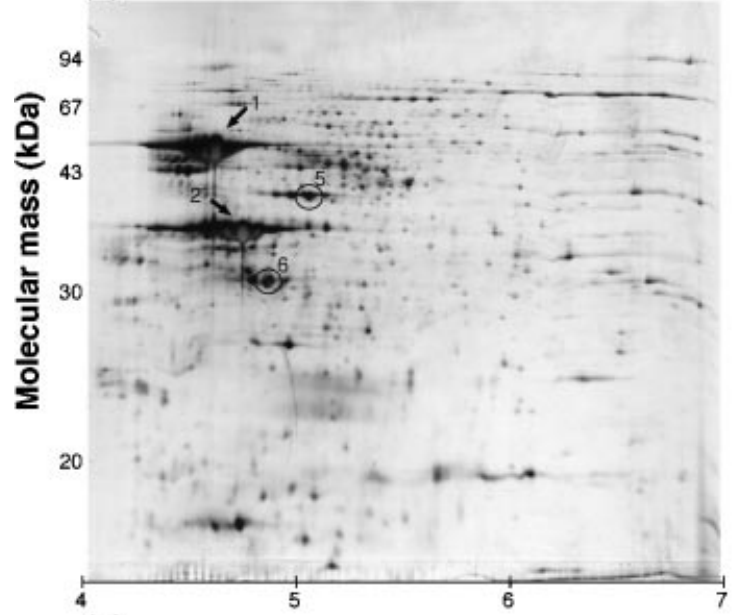

(e)

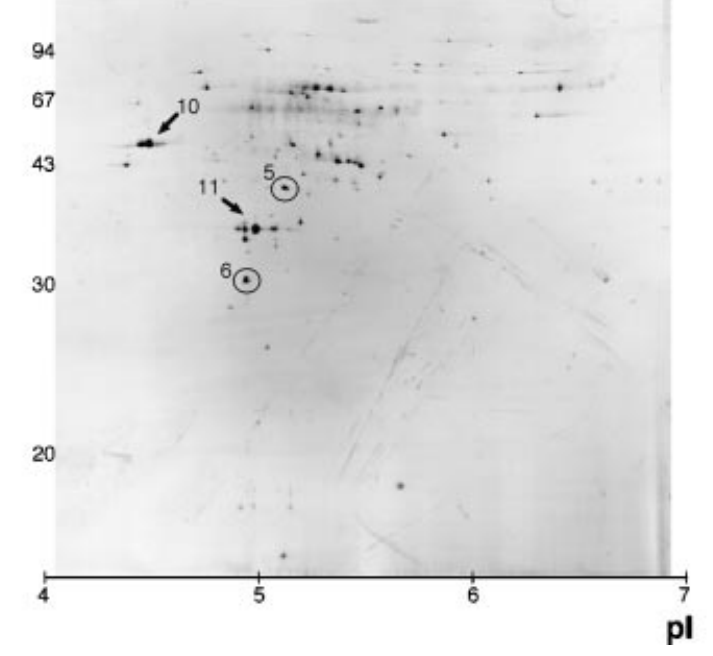

(b)

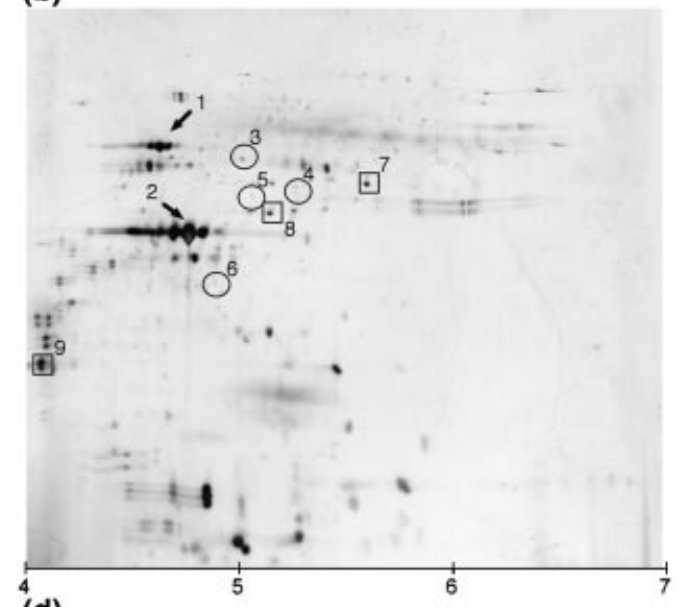

(d)

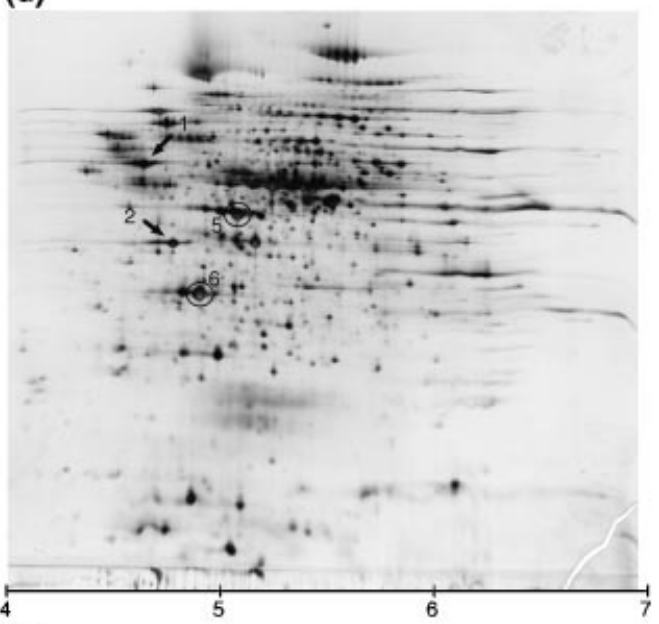

(f)

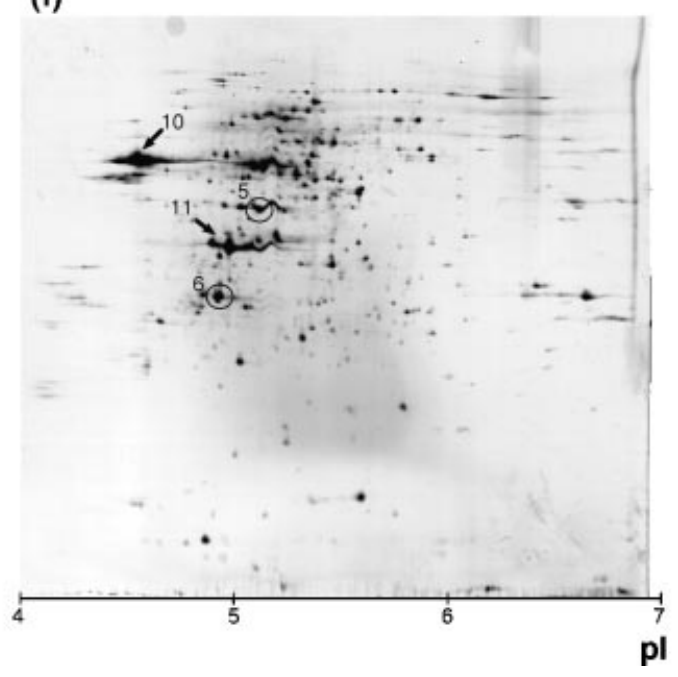

Fig. 2. C. difficile proteins analysed by 2-D PAGE. Samples from $24 \mathrm{~h} P Y$ and PYG cultures $\left(\mathrm{OD}_{600} 1 \cdot 3-1 \cdot 5\right)$ are shown in the panels. The toxins were not visualized because 2-D PAGE resolves large proteins poorly. (a-d) Samples from strain VPI 10463: (a) extracellular proteins from PY; (b) extracellular proteins from PYG; (c) high-speed pellet from PY (containing large protein complexes and proteins associated with the cell membrane and cell wall); (d) soluble (cytoplasmic) fraction from PY. (e, f) Samples from strain 630: (e) extracellular proteins from PY; (f) high-speed pellet from PY. The horizontal axes represent $\mathrm{pH}$ of the isoelectric focusing gradient; the vertical axes represent molecular masses in $\mathrm{kDa}$, based on migration of a molecular mass standard in the SDS electrophoresis gel. 
stained with Coomassie brilliant blue, and spots of interest were excised and N-terminally sequenced.

PCR amplification and restriction cleavage of $s / p A$. The primers used in the detection of the surface layer gene $s l p A$ were $5^{\prime}$-TATAATGTTGGGAGGAATTTAAGA-3' and $5^{\prime}$ CAAATCCAAATTCACTATTTGTAC-3'. The PCR was performed using Expand Long Template PCR System from Boehringer Mannheim (as specified by the manufacturer). After an initial denaturation at $92^{\circ} \mathrm{C}$ for $2 \mathrm{~min}$, the PCR cycle conditions were $92{ }^{\circ} \mathrm{C}$ for $10 \mathrm{~s}, 40^{\circ} \mathrm{C}$ for $30 \mathrm{~s}$, and $68^{\circ} \mathrm{C}$ for $2 \mathrm{~min}$ (30 cycles). The PCR products were cleaved with the restriction enzymes $R s a I$ (Boehringer Mannheim) and SauIIIA (Amersham Pharmacia Biotech). PCR and digestion products were separated on $0.8 \%$ agarose gels and visualized by ethidium bromide.

\section{RESULTS}

\section{Kinetics of toxin release by strain VPI 10463}

Toxin production by $C$. difficile is high in complex media (PY) but lowered by $>20$-fold in media containing excess glucose (PYG) (see Introduction). In PY, about $50 \%$ of the total toxin had become externalized after $40 \mathrm{~h}$ (Fig. 1a). Few spores $(<0 \cdot 1 \%)$ were found and only a small fraction of the population $(<1 \%)$ were broken or lysed. SDS-PAGE of PY cultures revealed two proteins, with mobilities of $290 \mathrm{kDa}$ and $270 \mathrm{kDa}$ (Fig. 1b), not observed in PYG (not shown). The amount of these proteins increased as $C$. difficile entered into stationary phase (Fig. 1b), and immunoprecipitation verified their identity as toxins $A$ and $B$ (Fig. 1c). The toxins co-immunoprecipitated using the toxin B antibody, and the identities of the bands, were further confirmed by Western blotting (not shown). By analysing the intensities of the toxin $\mathrm{A}$ and $\mathrm{B}$ bands on silver-stained gels, the ratio of total toxin A : toxin B was estimated to be $3: 1$ whereas the extracellular ratio was approximately $1: 1$ (Fig. 1d). These ratios were constant for at least $24 \mathrm{~h}$ in stationary phase, further arguing against bacterial lysis as the route of release of toxins $\mathrm{A}$ and B. A $47 \mathrm{kDa}$ protein was released with similar kinetics as the toxins (Fig. 1d) whereas most other extracellular proteins remained at constant levels (Fig. 1d, $205 \mathrm{kDa}$ protein).

\section{Identification of extracellular proteins in strain VPI 10463 by 2-D PAGE}

The extracellular protein pattern of strain VPI 10463 was much less complex than those of the membrane and intracellular fractions (Fig. 2; compare $\mathrm{a}$ and b with $\mathrm{c}$ and d) and also less complex than the extracellular protein pattern of strain 630 (compare Fig. 2e with 2a). Since strain 630 sporulates efficiently, presumably giving rise to partial lysis, and produces lower amounts of toxin than strain VPI 10463 during these conditions, we focused on the differences in extracellular protein between PY and PYG cultures of strain VPI 10463. The toxins, being $\approx 300 \mathrm{kDa}$ in molecular mass, were not visualized since 2-D PAGE resolves large $(150 \mathrm{kDa})$ proteins poorly. Four other extracellular proteins more abundant in PY than in PYG cultures (Fig. 2, spots 3-6) were identified.

As measured by the PDQuest 2-D software, the amount of spot 3 (a $47 \mathrm{kDa}$ protein) increased by $>10$-fold

Table 1. Extracellular proteins of $C$. difficile grown in PY and PYG medium identified by $\mathrm{N}$-terminal sequence analysis and database searches

\begin{tabular}{|c|c|c|c|c|c|}
\hline Spot* & $\begin{array}{l}\text { Mol. mass } \\
\quad(\mathrm{kDa})\end{array}$ & $\begin{array}{l}\text { Growth } \\
\text { medium }\end{array}$ & $\mathrm{N}$-terminal sequence & $\begin{array}{c}\text { Match in strain } 630 \\
\text { database } \dagger\end{array}$ & $\begin{array}{c}\text { Highest } \\
\text { homology } \neq\end{array}$ \\
\hline 1 & 50 & PY & AAKASIADENSPVKLTLKSDXKKDL & None & - \\
\hline 2 & 36 & PY & DDTKVETGDQGYTVV & Partial (ORF 1) & CwlB/LytC \\
\hline 3 & 47 & PY & SEKEILTARLAV & Complete, internal & TolC (weak) \\
\hline 4 & 40 & PY & AIGLPSINISSK & Complete, N-terminal & $\mathrm{XkdK}$ \\
\hline 5 & 39 & PY & MXDIKLDXFXKX & Complete, N-terminal & FixB \\
\hline 6 & 30 & PY & MKILVXVKQVXX & Complete, N-terminal & FixA \\
\hline 7 & 41 & PYG & AETTQVKKETIT & Complete, internal (ORF 2) & CwlB/LytC \\
\hline 8 & 38 & PYG & AETTQVKKETIT & Complete, internal (ORF 2) & CwlB/LytC \\
\hline 9 & 24 & PYG & TSLKIADEVGLD & Complete, internal (ORF 1) & CwlB/LytC \\
\hline 10 & 48 & PY & ANDTIASQDTPAKVV & Complete, internal (ORF 1) & CwlB/LytC \\
\hline 11 & 35 & PY & ATTGTQGYTVVKNDD & Complete, internal (ORF 1) & CwlB/LytC \\
\hline
\end{tabular}

*Spots 1-9 were from C. difficile strain VPI 10643; spots 10 and 11 were from C. difficile strain 630. See Fig. 2.

† Searches were made in the C. difficile strain 630 sequence database by the BLAST algorithm at http://www.sanger.ac.uk/ Projects/C_difficile/blast_server.shtml. ORF 1 and ORF 2 refer to Fig. 3(c). The N-terminal sequences of spot 2 showed a partial match with ORF 1 of strain 630 (cf. the underlined amino acids of spot 11 from strain 630). Internal means that the protein sequence started downstream of the predicted start codon of the ORF, i.e. the protein was processed at its $\mathrm{N}$-terminus.

$\ddagger C$. difficile contigs were exported to ORF finder at http://www.ncbi.nlm.nih.gov/gorf/, and the entire ORF was subjected to further pвLAst searches against the redundant database. CwlB/LytC and $\mathrm{XkdK}$ are from B. subtilis, TolC, FixA and FixB from E. coli. 
(a)

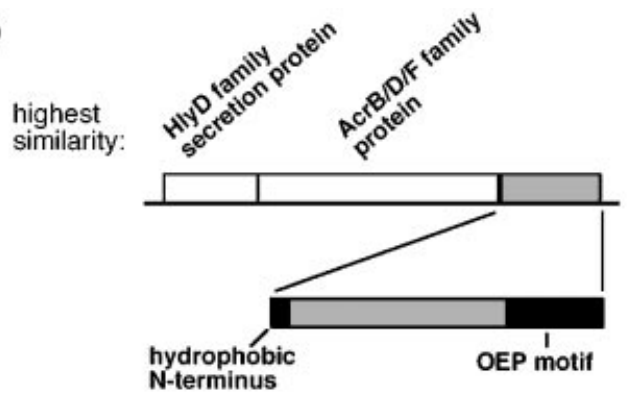

(b)

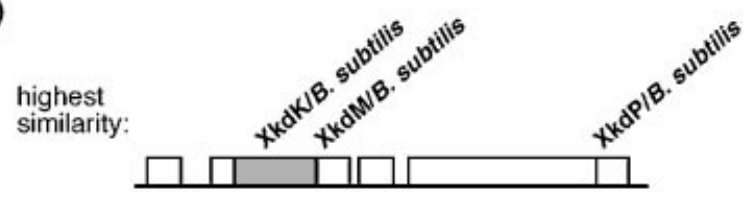

(c)

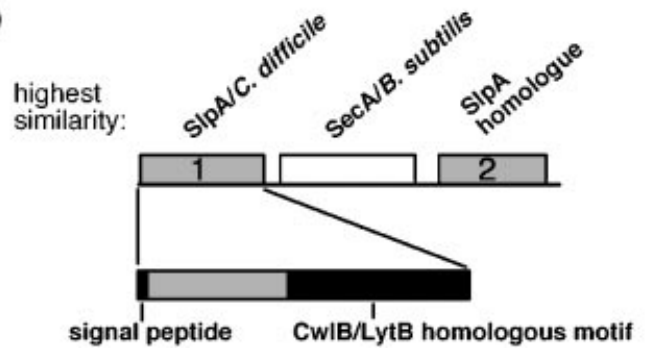

Fig. 3. Genes encoding extracellular proteins and their organization on the $C$. difficile chromosome. The panels show (a) the $49 \mathrm{kDa}$ TolC-like ORF, (b) the $40 \mathrm{kDa}$ XkdK-like ORF and (c) the $72 \mathrm{kDa}$ S-layer ORF (s/pA). ORFs 1 and 2 refer to those in Table 1. The genes encoding the extracellular proteins are shown in grey and adjacent genes in white. Similarities to other known proteins are indicated (see Results and Discussion for further information).

between $\mathrm{OD}_{600} 0.5$ and $\mathrm{OD}_{600} 1.3$ in PY (not shown) and was $>10$-fold less abundant in PYG supernatants (compare Fig. 2a with 2b). Its $\mathrm{N}$-terminal sequence matched with an ORF encoding a $49 \mathrm{kDa}$ protein in the C. difficile database and the C-terminal part showed weak similarity to outer-membrane efflux proteins of Gram-negative bacteria (Table 1, Fig. 3a, Fig. 4a).

The protein corresponding to spot 4 (a $40 \mathrm{kDa}$ protein) showed homology to XkdK (Table 1, Fig. 4b) encoded by the prophage PBSX in Bacillus subtilis. The C. difficile $x k d K$-like gene was located in a chromosomal segment of strain 630 that comprised several ORFs homologous to those from PBSX (Fig. 3b; XkdK, $\mathrm{XkdM}, \mathrm{XkdP}$ shown). The B. subtilis PBSX prophage is induced by the SOS response to e.g. the DNA-damaging agent mitomycin C (Okamoto et al., 1968; Seaman et al., 1964). However, neither the C. difficile XkdK homologue nor the toxins showed altered levels after addition of mitomycin C to PY or PYG cultures, a treatment that evidently caused induction of SOS since the cells started to form long filaments (not shown).

The PY-specific extracellular proteins 5 and 6 (39 and $30 \mathrm{kDa}$, respectively, Table 1) matched with two ORFs encoding proteins of 38 and $22 \mathrm{kDa}$, respectively, showing high similarity to FixB and FixA in Escherichia coli. The amounts of these were estimated to be $<1 \%$ of those in the intracellular fraction (compare Fig. 2a with $2 \mathrm{~d}$, spots 5 and 6) and their presence in the extracellular fraction may thus represent a small fraction of the bacterial population being lysed. Importantly, $<1 \%$ lysed cells cannot explain the efficient release of toxins from strain VPI 10463. The amounts of extracellular FixA and FixB were higher in strain 630 (Fig. 2e), confirming that this strain was more prone to lyse.

\section{Identification of the $\mathbf{C}$. difficile surface layer proteins}

The two most abundant extracellular proteins in strain VPI 10463 were present in both PY and PYG culture supernatants (Fig. 2a and $2 \mathrm{~b}$, spot $1[50 \mathrm{kDa}]$ and 2 [36 kDa]) and these were highly abundant in the highspeed pellet fraction, which contained mainly membrane vesicles, cell wall fragments and large protein complexes (compare Fig. 2c with Fig. 2a). In strain 630, two abundant proteins with similar molecular masses (48 and $35 \mathrm{kDa}$ ) and different $\mathrm{pI}$ values than those of strain VPI 10463 were found in the extracellular (Fig. 2e, spots 10 and 11) and particularly in the pellet fraction (Fig. 2f).

The $\mathrm{N}$-terminal sequence of the $50 \mathrm{kDa}$ protein (spot 1) from strain VPI 10463 did not show homology to any protein in the C. difficile strain 630 genome database whereas the N-terminus of the $36 \mathrm{kDa}$ protein (spot 2) showed partial similarity to the $72 \mathrm{kDa}$ C. difficile Slayer protein SlpA (Fig. 3c, Table 1). Spots 7 and 8 found in PYG cultures (Fig. 2b) matched with ORF 2 from the same genomic fragment and spot 9 matched with SlpA (Table 1). The $\mathrm{N}$-terminal sequences of spots 10 and 11 from strain 630 both matched with the SlpA ORF (Table 1). At least six other proteins less abundant than spots 1 and 2 were observed in both PY and PYG culture supernatants of strain VPI 10463 but were not further characterized. These results imply an extracellular or surface-located protelytic activity mainly involved in processing of the C. difficile S-layer protein.

\section{The C. difficile surface layer gene shows inter-strain diversity}

As reported by Calabi et al. (2001) and Karjalainen et al. (2001) we found that the gene segment containing the $C$. difficile S-layer gene slpA comprised $\sec A$ and several additional genes with high similarity to $\operatorname{sl} A$. The amino acid sequences of SlpA and the SlpA-like ORFs were characterized by a constant part showing significant homology to $\mathrm{N}$-acetylmuramoyl-L-alanine amidase (CwlB/LytC) and amidase enhancer protein (LytB) from B. subtilis (Table 1, Fig. 3c). The N-terminus of all the $\mathrm{N}$-acetylmuramoyl-L-alanine amidase-like ORFs contained a typical Sec-dependent signal peptide, and the 


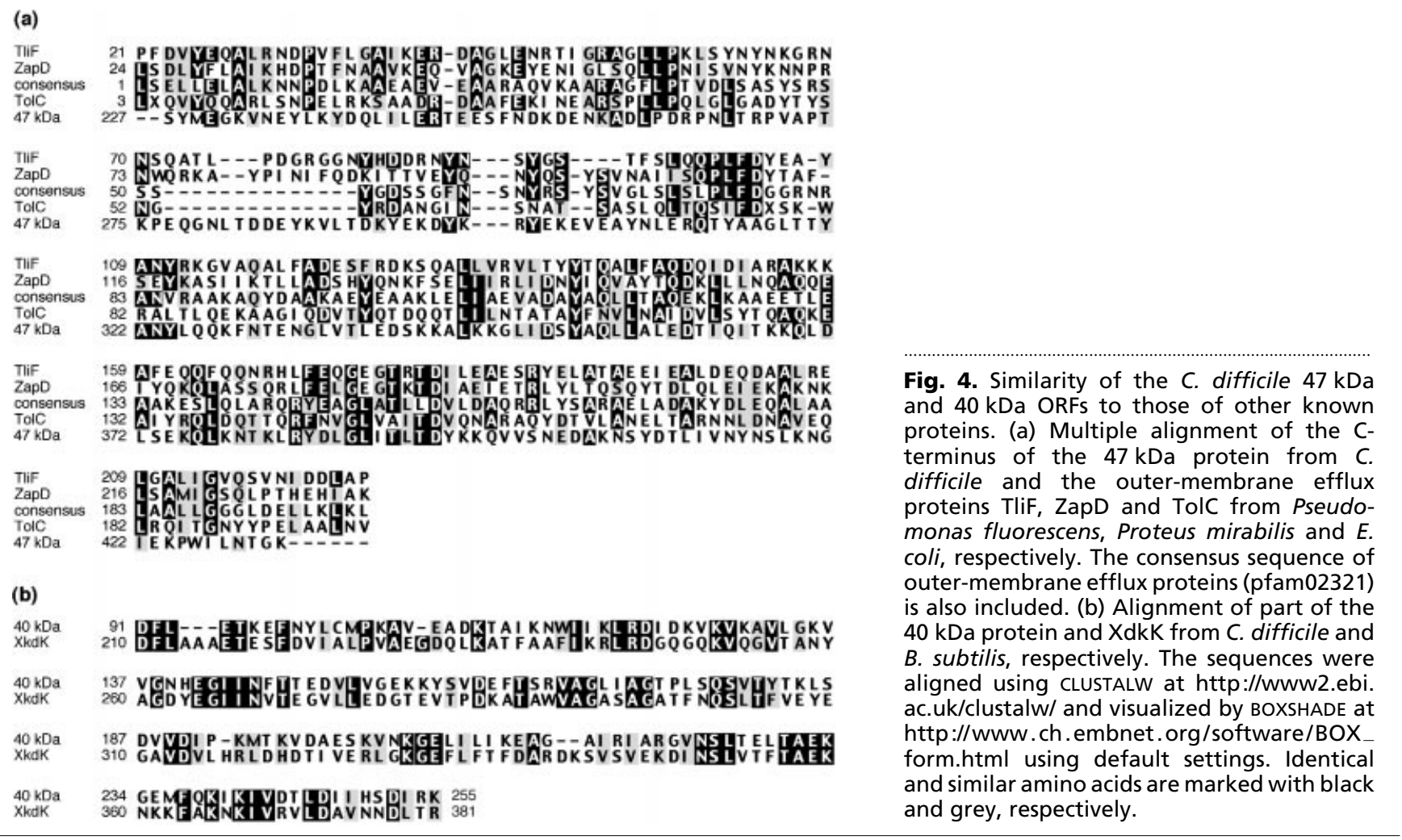

predicted cleavage site in SlpA from strain 630 was identical to that found in the extracellular form. However, no typical secondary protease processing site was found that would allow the further cleavage of the expected $72 \mathrm{kDa} S \operatorname{spA}$ protein to give the finally sized S-layer proteins of apparent molecular masses 48 and $35 \mathrm{kDa}$ in strain 630.

To test whether other $C$. difficile strains contained the slpA gene, a PCR with primers directed to the region upstream of $\operatorname{slp} A$ and to the $5^{\prime}$ part of $\sec A$ was applied to 18 serogroup type strains. All strains except those belonging to serogroups A, A5 and S4 yielded one major PCR product of approximately $2900 \mathrm{bp}$, although that of serogroup $\mathrm{H}$ was slightly larger (Fig. 5a). Thus the upstream region of $\operatorname{slp} A$ and $\sec A$ and the size of the intervening DNA appeared to be conserved in most strains of C. difficile. Digestion of the PCR fragments using the restriction enzymes SauIIIA and RsaI revealed that each type strain yielded a distinct and unique banding pattern (Fig. 5b, c). The pattern of strain 630 and VPI 10463 was identical to that of the serogroup C and $G$ type strains, respectively. In summary, these results showed that the $C$. difficile S-layer genes contain both constant and variable domains and the latter may be useful for grouping and typing of various C. difficile isolates.

\section{DISCUSSION}

It has been reported that export of toxins $A$ and $B$ by $C$. difficile correlates with a decrease in the number of vegetative cells and a concomitant appearance of spores
(Kamiya et al., 1992; Ketley et al., 1984), suggesting that the toxins are released by lysis during the sporulation process. Another study showed no correlation between release of toxin A and sporogenesis (Ketley et al., 1986), and this was confirmed here in the high-toxin-producing and low-sporulating strain VPI 10463. The small amounts of typical cytoplasmic proteins such as FixA and FixB in the culture supernatant of strain VPI 10463 probably reflected a small fraction of lysed cells $(<1 \%)$, but this cannot explain the efficient toxin release $(50 \%)$. As the toxins lack typical Sec-dependent signal peptides, this result indicates that the toxins are exported via another mechanism. Strain 630 had a more complex extracellular protein pattern than strain VPI 14063, most likely reflecting more lysis due to increased sporulation efficiency. Lysis associated with sporulation to release toxin is probably not important for disease development, as we have found that strain VPI 10463 caused severe diarrhoea in gnotobiotic mice (unpublished).

As compared to B. subtilis (Antelmann et al., 2001) the repertoire of extracellular proteins in C. difficile was small (about 15 vs 200 proteins), possibly reflecting the different ecological niches of the organisms. The $47 \mathrm{kDa}$ extracellular C. difficile protein found during high toxin production (PY cultures), was identified as an ORF with weak similarity to outer-membrane efflux proteins (OEPs) of Gram-negative bacteria, e.g. TolC (Fig. 4a). This ORF contained a putative signal peptide for export via the Sec-dependent pathway (Economou, 1999; Izard \& Kendall, 1994). The extracellular form was truncated downstream of the predicted signal peptide cleavage site, suggesting that its release was a 


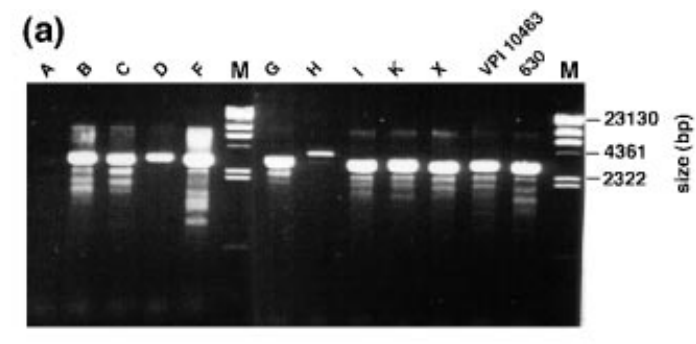

(b)
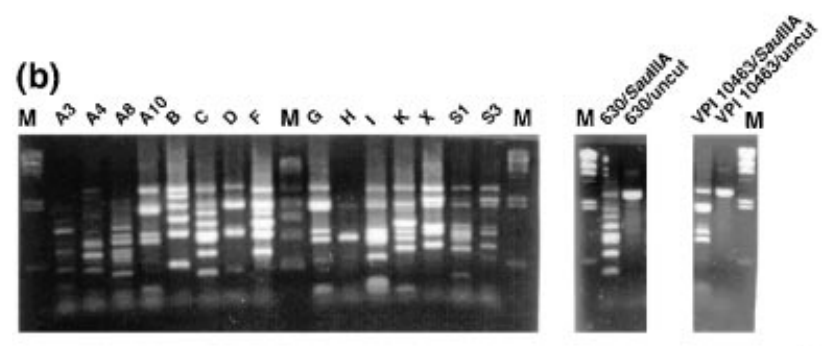

(c)

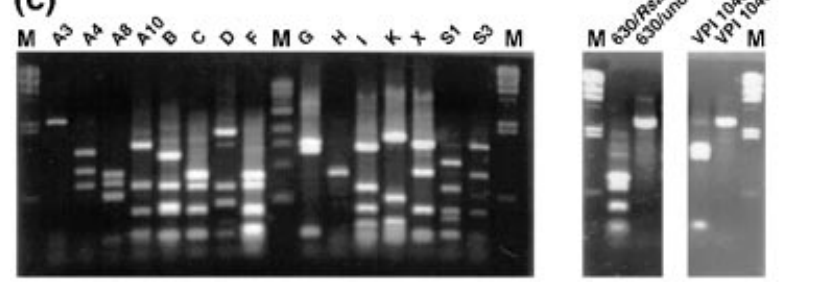

Fig. 5. Restriction enzyme cleavage patterns of $P C R$ products from the s/pA-secA gene segment in C. difficile. (a) Electrophoretic analysis of PCR products from 10 serotype reference strains, VPI 10463 and 630 (results from serotypes A3, A4, A5, A8, A10, S1, S3 and S4 not shown). Hindlll-digested $\lambda$ DNA was used as size marker (M). (b) Electrophoretic analysis of SaullIA digests of the PCR products. (c) As in (b) but Rsal digests.

result of further proteolytic digestion. The two adjacent ORFs encoded proteins similar to cation/multidrug resistance efflux pumps of the $A c r B / D / F$ family and periplasmic membrane fusion proteins of the HlyD family (Fig. 4a). These proteins, including TolC, are thought to form a continuous channel that traverses both the inner and the outer membrane in Gramnegative bacteria, and enable direct transport of molecules to the extracellular compartment via protonmotive force (Paulsen et al., 1996; Zgurskaya \& Nikaido, 2000). A similar architecture is found also in the type I secretion system which transports toxins in some Gram-negative bacteria, but the multidrug efflux pump protein is replaced by an ATPase. The three genes found in C. difficile may thus constitute a novel type of transporter system in Gram-positive bacteria that traverses both the cell membrane and the cell wall. The PYspecific XkdK-like protein neither contained a typical signal peptide, nor was processed at its $\mathrm{N}$-terminus. Its gene was found in a segment on the C. difficile chromosome containing several genes similar to those encoded by the phage-like element PBSX in B. subtilis (Krogh et al., 1996). B. subtilis also releases PBSX proteins including $\mathrm{XkdK}$ into the culture supernatant during growth in LB medium, most likely via phagespecific holins (Antelmann et al., 2001). Interestingly, the $t c d E$ gene located between the genes for toxin $\mathrm{A}$ and $\mathrm{B}$ in the pathogenicity locus of $\mathrm{C}$. difficile encodes a putative holin (Tan et al., 2000), suggesting that the toxins and the $\mathrm{XkdK}$ homologue may be secreted via similar mechanisms.

The S-layer of C. difficile is composed of two proteins with apparent molecular masses of 32-36 and 45$47 \mathrm{kDa}$ and has been characterized previously at the genomic, protein and structural levels (Calabi et al., 2001; Cerquetti et al., 2000; Karjalainen et al., 2001; Mauri et al., 1999; Takeoka et al., 1991; Waligora et al., 2001). The two highly abundant extracellular and membrane fraction proteins in strain 630 were identical to the S-layer protein SlpA-630/C253 (Karjalainen et al., 2001). The differences in size and particularly pI between the S-layer proteins of strains 630 and VPI 10643 as shown by $2 \mathrm{D}-\mathrm{PAGE}$ indicate significant sequence variation of the S-layer protein among different strains. A significant variation in $\mathrm{pI}$ of these proteins was also observed for other serogroup type strains (unpublished). The restriction cleavage pattern of PCR products from the $\operatorname{sip} A-\sec A$ region of various serogroup reference strains verified this sequence variability and also that strains 630 and VPI 10463 showed patterns identical to reference strains representing those of serogroup $C$ and G, respectively. Using PCR ribotyping (Stubbs et al., 1999), we found strain 630 to be of PCR ribotype 12, whose reference strain again belongs to serogroup C. Strain 630 has however been assigned to serogroup $\mathrm{X}$ (cf. http://www.sanger.ac.uk/Projects/C_difficile/), a result that is not in agreement with these data. This indicates that serotyping may give ambiguous results (or that strain 630 has been assigned to the wrong serogroup), or that the strain has switched its $s l p A$ gene. Strain VPI 10463 clustered by PCR ribotyping close to a group belonging to serogroup $\mathrm{G}$ (unpublished). The PCR ribotype of VPI 10463 is not determined according to the nomenclature of Stubbs et al. (1999) but the Nterminal sequences of its S-layer proteins were identical to those of a strain belonging to PCR ribotype 1 (Calabi et al., 2001), whose reference strain belongs to serogroup G. These data show that S-layer genomic typing methods should be developed for improved molecular typing of C. difficile strains.

The C-terminal part of SlpA showed significant homology to $\mathrm{N}$-acetylmuramoyl-L-alanine amidase (CwlB/ LytC) and amidase enhancer protein $(\mathrm{LytB})$ from $B$. subtilis (Lazarevic et al., 1992), which confirmed recent findings (Calabi et al., 2001; Karjalainen et al., 2001). This motif may thus have cell wall peptidoglycan binding properties. Karjalainen et al. (2001) suggested that the N-terminal part of C. difficile SlpA has homology to the SLH domain present in many S-layer proteins (cf. Lupas et al., 1994), but like Calabi et al. (2001) we did not find such similarity at the sequence level. It is possible, however, that this part of the $C$. 
difficile S-layer protein shows weak similarities to that of the SLH domain.

Considering the highly competitive situation of closely related organisms in their natural habitats, it is obvious that the S-layer has to contribute to diversification rather than to conservation. With respect to this, the importance of S-layer variation during different stress conditions such as those imposed by the immune system of a host in response to an S-layered pathogen or drastic changes in the growth and environmental conditions for non-pathogens is conceivable (Dworkin \& Blaser, 1997; Luckevich \& Beveridge, 1989; Sa'ra et al., 1996). A protein named Cwp66 encoded in the same chromosomal segment as SlpA was shown to have putative adhesive properties to eukaryotic cells (Waligora et al., 2001). Moreover, it was shown by RT-PCR that most ORFs in the S-layer gene segment were simultaneously transcribed (Calabi et al., 2001), although the protein yield (as found here) may differ significantly between the ORFs. Whether the different S-layer ORFs in this chromosomal segment have similar or different functions and are under common or different regulatory control is yet to be verified. An interesting question is whether these genes are important for disease development and whether changes of organization or expression of the S-layer genes occur in vivo.

\section{ACKNOWLEDGEMENTS}

This research was supported by a postdoctoral fellowship to K.M. from AstraZeneca Research Foundation India (AZREFI), Bangalore, India. Amino acid sequence data were obtained at the Protein Analysis Center, Karolinska Institute, Stockholm, Sweden. C. difficile strain 630 was obtained as a kind gift from Peter Mullany.

\section{REFERENCES}

Antelmann, H., Tjalsma, H., Voigt, B., Ohlmeier, S., Bron, S., van Dijl, J. M. \& Hecker, M. (2001). A proteomic view on genomebased signal peptide predictions. Genome Res 11, 1484-1502.

Braun, V., Hundsberger, T., Leukel, T., Sauerborn, M. \& von Eichel-Streiber, C. (1996). Definition of the single integration site of the pathogenicity locus in Clostridium difficile. Gene 181, 29-38.

Calabi, E., Ward, S., Wren, B., Paxton, T., Panico, M., Morris, H., Dell, A., Dougan, G. \& Fairweather, N. (2001). Molecular characterization of the surface layer proteins from Clostridium difficile. Mol Microbiol 40, 1187-1199.

Cerquetti, M., Molinari, A., Sebastianelli, A., Diociaiuti, M., Petruzzelli, R., Capo, C. \& Mastrantonio, P. (2000). Characterization of surface layer proteins from different Clostridium difficile clinical isolates. Microb Pathog 28, 363-372.

Dove, C. H., Wang, S.-Z., Price, S. B., Phelps, C. J., Lyerly, D. M., Wilkins, T. D. \& Johnson, J. L. (1990). Molecular characterization of the Clostridium difficile toxin A gene. Infect Immun 58, 480-488.

Dupuy, B. \& Sonenshein, A. L. (1998). Regulated transcription of Clostridium difficile toxin genes. Mol Microbiol 27, 107-120.

Dworkin, J. \& Blaser, M. J. (1997). Molecular mechanisms of Campylobacter fetus surface layer protein expression. Mol Microbiol 26, 433-440.
Economou, A. (1999). Following the leader: bacterial protein export through the Sec-pathway. Trends Microbiol 7, 315-319.

Hammond, G. A. \& Johnson, J. L. (1995). The toxigenic element of Clostridium difficile strain VPI 10463. Microb Pathog 19, 203-213.

Hammond, G. A., Lyerly, D. M. \& Johnson, J. L. (1997). Transcriptional analysis of the toxigenic element of Clostridium difficile. Microb Pathog 22, 143-154.

Haslam, S. C., Ketley, J. M., Mitchell, T. J., Stephen, J., Burdon, D. W. \& Candy, D. C. A. (1986). Growth of Clostridium difficile and production of toxins A and B in complex and defined media. J Med Microbiol 21, 293-297.

Hundsberger, H., Braun, V., Weidmann, M., Leukel, P., Sauerborn, M. \& von Eichel-Streiber, C. (1997). Transcription analysis of the genes $t c d A-E$ of the pathogenicity locus of Clostridium difficile. Eur J Biochem 244, 735-742.

Izard, J. W. \& Kendall, D. A. (1994). Signal peptides: exquisitely designed transport promoters. Mol Microbiol 13, 765-773.

Kamiya, S., Ogura, H., Meng, X. Q. \& Nakamura, S. (1992). Correlation between cytotoxin production and sporulation in Clostridium difficile. J Med Microbiol 37, 206-210.

Karjalainen, T., Waligora-Dupriet, A. J., Cerquetti, M., Spigaglia, P., Maggioni, A., Mauri, P. \& Mastrantonio, P. (2001). Molecular and genomic analysis of genes encoding surface-anchored proteins from Clostridium difficile. Infect Immun 69, 3442-3446.

Karlsson, S., Burman, L. G. \& Åkerlund, T. (1999). Suppression of toxin production in Clostridium difficile VPI 10463 by amino acids. Microbiology 145, 1683-1693.

Karlsson, S., Lindberg, A., Norin, E., Burman, L. G. \& Åkerlund, T. (2000). Toxins, butyric acid and other short chain fatty acids are co-ordinately expressed and down regulated by cysteine in Clostridium difficile. Infect Immun 68, 5881-5888.

Ketley, J. M., Haslam, S. C., Mitchell, T. J., Stephen, J., Candy, D. C. A. \& Burdon, D. W. (1984). Production and release of toxins A and B by Clostridium difficile. J Med Microbiol 18, 385-391.

Ketley, J. M., Mitchell, T. J., Haslam, S. C., Stephen, J., Candy, D. C. A. \& Burdon, D. W. (1986). Sporogenesis and toxin A production by Clostridium difficile. J Med Microbiol 22, 33-38.

Krogh, S., O'Reilly, M., Nolan, N. \& Devine, K. M. (1996). The phage-like element PBSX and part of the skin element, which are resident at different locations on the Bacillus subtilis chromosome, are highly homologous. Microbiology 142, 2031-2040.

Lazarevic, V., Margot, P., Suldo, B. \& Karamata, D. (1992). Sequencing and analysis of the Bacillus subtilis lytRABC divergon: a regulatory unit encompassing the structural genes of the $\mathrm{N}$-acetylmuramoyl-L-alanine amidase and its modifier. $J$ Gen Microbiol 138, 1949-1961.

Luckevich, M. D. \& Beveridge, T. J. (1989). Characterization of a dynamic S-layer on Bacillus thuringiensis. J Bacteriol 171, 6656-6667.

Lupas, A., Engelhardt, H., Peters, J., Santarius, U., Volker, S. \& Baumeister, W. (1994). Domain structure of the Acetogenium kivui surface layer revealed by electron crystallography and sequence analysis. J Bacteriol 176, 1224-1233.

Lyerly, D. M. \& Wilkins, T. D. (1986). Commercial latex test for Clostridium difficile toxin A does not detect toxin A. J Clin Microbiol 23, 622-623.

Lyerly, D. M. \& Wilkins, T. D. (1995). Clostridium difficile. In Infections of the Gastrointestinal Tract, pp. 867-891. Edited by M. J. Blaser, P. D. Smith, J. I. Ravdin, H. B. Greenberg \& R. L. Guerrant. New York: Raven Press. 
Mani, N. \& Dupuy, B. (2001). Regulation of toxin synthesis in Clostridium difficile by an alternative RNA polymerase sigma factor. Proc Natl Acad Sci U S A 98, 5844-5849.

Mauri, P. L., Pietta, P. G., Maggioni, A., Cerquetti, M., Sebastianelli, A. \& Mastrantonio, P. (1999). Characterization of surface layer proteins from Clostridium difficile by liquid chromatography/ electrospray ionization mass spectrometry. Rapid Commun Mass Spectrom 13, 695-703.

Moncrief, J. S., Barroso, L. A. \& Wilkins, T. D. (1997). Positive regulation of Clostridium difficile toxins. Infect Immun $\mathbf{6 5}$, 1105-1108.

Okamoto, K., Mudd, J. A. \& Marmur, J. (1968). Conversion of Bacillus subtilis DNA to phage DNA following mitomycin C. J Mol Biol 137, 261-267.

Onderdonk, A. B., Lowe, B. R. \& Bartlett, J. G. (1979). Effect of environmental stress on Clostridium difficile toxin levels during continuous cultivation. Appl Environ Microbiol 38, 637-641.

Paulsen, I. T., Brown, M. H. \& Skurray, R. A. (1996). Protondependent multidrug efflux systems. Microbiol Rev 60, 575-608.

Sa'ra, M., Kuen, B., Mayer, H. F., Mandl, F., Schuster, K. C. \& Sleytr, U. B. (1996). Dynamics in oxygen induced changes in Slayer protein synthesis from Bacillus stearothermophilus PV72 and the S-layer deficient variant T5 in continuous culture and studies on the cell wall composition. J Bacteriol 178, 2108-2117.

Seaman, E., Tarmy, E. \& Marmur, J. (1964). Inducible phages of Bacillus subtilis. Biochemistry 3, 607-612.

Stubbs, S. L., Brazier, J. S., O’Neill, G. L. \& Duerden, B. I. (1999). PCR targeted to the 16S-23S rRNA gene intergenic spacer region of Clostridium difficile and construction of a library consisting of 116 different PCR ribotypes. J Clin Microbiol 37, 461-463.
Takeoka, A., Takumi, K., Koga, T. \& Kawata, T. (1991). Purification and characterization of S-layer proteins from Clostridium difficile GAI 0714. J Gen Microbiol 137, 261-267.

Tan, K. S., Wee, B. Y. \& Song, K. P. (2000). Evidence for holin function of $t c d E$ gene in the pathogenicity of Clostridium difficile. J Med Microbiol 50, 613-619.

von Eichel-Streiber, C., Laufenberg-Feldman, R., Sartingen, S., Schulze, J. \& Sauerborn, M. (1992). Comparative sequence analysis of the Clostridium difficile toxins A and B. Mol Gen Genet 233, 260-268.

von Eichel-Streiber, C., Boquet, P., Sauerborn, M. \& Thelestam, M. (1996). Large clostridial cytotoxins - a family of glycosyltransferase modifying small GTP-binding proteins. Trends Microbiol 4, 375-382.

Waligora, A. J., Hennequin, C., Mullany, P., Bourlioux, P., Collignon, A. \& Karjalainen, T. (2001). Characterization of a cell surface protein of Clostridium difficile with adhesive properties. Infect Immun 69, 2144-2153.

Yamakawa, K., Kamiya, S., Meng, X. Q., Karasawa, T. \& Nakamura, S. (1994). Toxin production by Clostridium difficile in a defined medium with limited amino acids. J Med Microbiol 41, 319-323.

Yamakawa, K., Karasawa, T., Ikoma, S. \& Nakamura, S. (1996). Enhancement of Clostridium difficile toxin production in biotinlimited conditions. J Med Microbiol 44, 111-114.

Zgurskaya, H. I. \& Nikaido, H. (2000). Cross-linked complex between oligomeric periplasmic lipoprotein AcrA and the innermembrane-associated multidrug efflux pump AcrB from Escherichia coli. J Bacteriol 182, 4264-4267.

Received 11 March 2002; accepted 8 April 2002. 